\title{
SYTUACJA PSYCHOSPOLECZNA RODZIN Z PROBLEMEM UZALEŻNIENIA
}

\begin{abstract}
Streszczenie
Uzależnienie nie jest wyłacznie problemem chorego, przeciwnie - rodzina, będac najbliższym środowiskiem osoby uzależnionej bardzo mocno narażona jest na jej destrukcyjny wplyw. Nałóg jednego z członków najczęściej zaburza bowiem funkcje i strukture catego systemu rodzinnego. Celem artykułu jest dokonanie empirycznej ilustracji sytuacji psychospołecznej rodzin z problemem uzależnienia - ustalenie jak sami pacjenci poradni odwykowych oceniaja swoje relacje rodzinne. Do udziatu w badaniu zaproszono zarówno osoby uzależnione od substancji psychoaktywnych (alkoholu i narkotyków), jak $i$ różnego rodzaju zachowań (głównie seksu i hazardu). Narzędziem gromadzenia danych byt autorski kwestionariusz ankiety.
\end{abstract}

Słowa kluczowe: uzależnienie, relacje rodzinne, kryzys, choroba, przemoc w rodzinie

\section{Uzależnienia jako ,choroba rodziny”}

Rodzina postrzegana jest jako najstarszy i jednocześnie najtrwalszy element organizacji społecznej, związany z małżeństwem, prokreacją i wychowaniem dzieci. Tą niewielką grupę społeczną cechuje specyficzny rodzaj więzi wyznaczony bliskimi relacjami, z czego wynika, że nie jest ona luźnym zbiorem jednostek ${ }^{1}$.

* Mgr Julia Dziukiewicz - pedagog, Katedra Pedagogiki Społecznej, Instytut Pedagogiki Uniwersytet Śląski w Katowicach.

1 E. Syrek, Zdrowie $i$ wychowanie a jakość życia. perspektywy i humanistyczne orientacje poznawcze, Wydawnictwo Uniwersytetu Śląskiego, Katowice 2008, s. 93-131. 
Różni autorzy analizujący zdrowie rodziny podkreślają wzajemne powiązania między zdrowiem i chorobą a funkcjonowaniem tego systemu. Zwykle rozpatrywane są one w trzech aspektach: rola rodziny w kształtowaniu zdrowia jej członków, znaczenie rodziny w obliczu choroby jednego z nich oraz wpływ jego choroby na funkcjonowanie całego systemu rodzinnego ${ }^{2}$. Jeśli chodzi o sposób w jaki choroba oddziałuje na rodzinę, obserwuje się zarówno przeciążenie i występowanie sytuacji szczególnie trudnych, jak i pogłębienie więzi i zbliżenie emocjonalne ${ }^{3}$, a zatem może ona stanowić nie tylko czynnik zagrażający rodzinie, ale także umacniający ją.

Rodzina, jako najbliższe środowisko osoby uzależnionej jest najbardziej narażona na jej destrukcyjny wpływ. Choroba - jak pisze D. Chlebio-Abed ${ }^{4}$ - zaburza zarówno funkcje, jak i strukturę systemu rodzinnego. W opinii autorki, alkohol upośledza właściwe pełnienie niemal wszystkich funkcji typowych dla rodziny - a w sposób szczególny tych prokreacyjnych, bytowo-opiekuńczych i socjalizacyjnych. Jest także częstą przyczyną rozpadu rodzin, które stają się niepełne nie tylko na skutek śmierci alkoholika czy pijanej ofiary wypadku, ale również w wyniku separacji, rozwodu lub długotrwałej nieobecności chorego, który podjął leczenie odwykowe. Na katastrofalne konsekwencje nałogu zwracają uwagę także D. Kozłowska i J. Łodzińska ${ }^{5}$, zdaniem których w rodzinie alkoholowej często dochodzi do przemocy ze strony alkoholika, destrukcji roli rodzica, braku odpowiedzialności czy niewierności małżeńskiej.

Uzależnienie często ujmowane jest jako „choroba rodziny”, ponieważ nałóg jednego z członków odciska swoje piętno na każdym w rodzinie i zarazem każdy na swój sposób uczestniczy w powstawaniu i utrzymywaniu tego zaburzenia ${ }^{6}$. Stawanie się rodziną alkoholową, jest procesem w wyniku którego wprowadzony do rodziny alkohol i jego spożywanie przez jedną lub więcej osób staje się główną

2 I. Taranowicz, Rodzina a problemy zdrowia i choroby, w: Zdrowie i choroba. Wybrane problemy socjologii medycyny, red. J. Barański, W. Piątkowski, Wydawnictwo Oświatowe ATUT, Wrocław 2002, s. 105.

3 Z. Kawczyńska-Butrym, Wyzwania rodziny: zdrowie, choroba, niepełnosprawność, starość, Wydawnictwo Makmed, Lublin 2008, s. 85.

4 D. Chlebio-Abed, Pierwotna profilaktyka uzależnienia od alkoholu. Przeglad wybranych strategii i programów, Wydawnictwo Naukowe „Śląsk”, Katowice 2010, s. 42.

5 D. Kozłowska i J. Łodzińska, Świadomość skutków zdrowotnych nadużywania alkoholu przez dorostych na podstawie badań przeprowadzonych w śród młodzieży gimnazjalnej i osób dorosłych w Łomży. „Zeszyty Naukowe. Wyższa Szkoła Agrobiznesu w Łomży” 2013, nr 49, s. 95-104.

6 P. Szczukiewicz, System rodzinny a pomaganie osobom uzależnionym. „Terapia: uzależnienia i współuzależnienia” 2013, nr 2, s. 7-11. 
zasadą organizującą i kształtującą życie rodziny. W rezultacie pewnego dnia członkowie tego systemu zaczynają dostrzegać, że całe ich życie koncertuje się wokół psychoaktywnej substancjił. Konieczność funkcjonowania w takim układzie społecznym determinuje wiele dysfunkcji w różnych obszarach życia rodzinnego. J. Mallibruda ${ }^{8}$ wskazuje przede wszystkim na:

- $\quad$ niszczenie sfery uczuciowej - zamiast poczucia bezpieczeństwa, zaufania i miłości, członkom rodziny towarzysz lęk i niepewność, poczucie krzywdy, złość i gniew oraz wstyd i poczucie winy;

- $\quad$ brak źródeł wsparcia i wzajemnej pomocy - członkowie systemu przestają być dla siebie oparciem, stają się natomiast coraz większym obciążeniem;

- utrata kontaktu i wzajemnego zrozumienia - otwartość i prawda odchodzi w zapomnienie ustępując miejsca licznym kłamstwom i manipulacji;

- zamknięcie na świat zewnętrzny - w swojej tragedii i cierpieniu rodzina izoluje się od innych;

- wyczerpanie zasobów finansowych - nałóg staje się przyczyną poważnych kłopotów w sferze materialnej ograniczając jednocześnie perspektywy bytowe całej rodziny.

Członkowie rodziny starają się przystosować do zagrażających sytuacji tworzonych przez osobę uzależnioną. Takie przystosowanie z jednej strony ułatwia przetrwanie w trudnych i bolesnych momentach, $z$ drugiej natomiast - staje się pułapką, w której zostaje zamknięte pragnienie normalnego i bezpiecznego życia rodzinnego'.

\section{Najważniejsze założenia metodologiczne}

Celem pracy jest przedstawienie sytuacji psychospołecznej rodzin z problemem uzależnienia - ustalenie jak kształtują się relacje rodzinne osób chorych, zmagających się z nałogiem. Wyniki badań, które zostaną zaprezentowane w niniejszym artykule stanowią fragment szerszego projektu badawczego poświęconego jakości życia osób uzależnionych. Wspomniane badania realizowano w okresie od lipca do grudnia 2015 roku. Ponieważ zostały one zaplanowane jako diagnostyczne,

7 M. Jedynak, Alkoholizm jako zjawisko patologiczne i spolecznie destruktywne, w: Uzależnienia oraz zwiazane z nimi zagrożenia społeczne, red. D. Pstrąg, Wydawnictwo Uniwersytetu Rzeszowskiego, Rzeszów 2014, s. 112.

8 J. Mellibruda, Tajemnice ETOH, czyli alkohol i nasze życie, PARPA, Warszawa 1993, s. 35 .

A. Ryszkowski, Funkcjonowanie w społeczeństwie osób uzależnionych od alkoholu. „Journal of Clinical Healthcare” 2015, nr 1, s. 7-13. 
w toku konceptualizacji zrezygnowano ze stawiania hipotez ${ }^{10}$. Jednocześnie z uwagi na przyjęty paradygmat ilościowy - zdecydowano się na zastosowanie metody sondażu diagnostycznego z techniką ankiety. Narzędziem gromadzenia danych był autorski kwestionariusz ankiety. Jako teren badań wybrano ośrodki terapii uzależnień zlokalizowane w różnych miastach województwa Śląskiego: Katowicach, Zabrzu, Sosnowcu, Siemianowicach Śląskich, Dąbrowie Górniczej, Tychach. Dobór próby miał charakter celowy i opierał się na kryteriach medycznych. Do udziału w badaniach zaproszono zarówno osoby uzależnione od substancji psychoaktywnych (alkoholu, narkotyków), jak i różnego rodzaju zachowań (głównie seksu i hazardu).

W badaniach wzięło udział 250 osób - pacjentów rozpoczynających leczenie. $Z$ tej próby badawczej, do dalszych analiz zakwalifikowano 237 ankiet. Zgodnie z literaturą przedmiotu można przyjąć, że liczba ta jest wystarczająca do przeprowadzenia badań (próba licząca nie mniej niż 100 jednostek - to próba duża) ${ }^{11}$.

Tabela 1. Charakterystyka osób badanych

\begin{tabular}{|l|c|c|}
\hline & Liczba & Procenty \\
\hline Płeć badanych & & \\
\hline Kobieta & 82 & 34,60 \\
\hline Mężczyzna & 155 & 65,40 \\
\hline Wiek badanych & & \\
\hline $18-29$ & 39 & 16,45 \\
\hline $30-39$ & 67 & 28,27 \\
\hline $40-49$ & 47 & 27,43 \\
\hline $50-59$ & 19 & 8,02 \\
\hline $60-69$ & & 16,88 \\
\hline Poziom wykształcenia & 40 & \\
\hline Wyższe & 65 & \\
\hline
\end{tabular}

10 Zob. A.W. Maszke, Metody i techniki badań pedagogicznych, Wydawnictwo Uniwersytetu Rzeszowskiego, Rzeszów 2008, s. 111.

11 Zob. T. Pilch, T. Bauman, Zasady badań pedagogicznych: strategie ilościowe i jakościowe, Wydawnictwo Akademickie „Żak”, Warszawa 2001, s. 130. 


\begin{tabular}{|l|c|c|}
\hline & Liczba & Procenty \\
\hline Średnie & 116 & 48,95 \\
\hline Zawodowe & 64 & 27,00 \\
\hline Podstawowe & 17 & 7,17 \\
\hline
\end{tabular}

Źródło: badania własne

Badaną populację stanowiło 155 mężczyzn i 82 kobiety w wieku od 18 do 69 lat. Średni wiek respondentów w przybliżeniu wynosił 42 lata. Osoby uczestniczące w badaniu nie tylko charakteryzowały się różnym wiekiem, ale również reprezentowały niejednakowy poziom wykształcenia. Zdecydowanie największa cześć ankietowanych legitymowała się wykształceniem średnim - 116 respondentów (zob. tab. 1.).

\section{Analiza wyników i dyskusja}

Charakterystykę systemu rodzinnego oraz funkcjonowania w nim badanej populacji rozpoczęto od ustalenia, jak respondenci sami oceniają swoje życie rodzinne (zob. rys. 1.). Uzyskane wyniki badań wykazały, że większość respondentów $(48,52 \%)$ ocenia funkcjonowanie rodziny na poziomie przeciętnym, wskazując jednocześnie na rozluźnienie więzi pomiędzy członkami i brak wzajemnej bliskości. Rzadziej $(32,91 \%)$ ankietowani określali swoje życie rodzinne jako „dobre”. Osoby te deklarowały, że lubią spędzać czas z bliskimi, dużo rozmawiają i stanowią dla siebie oparcie w trudnych chwilach. Taka wspierająca postawa najbliższych oraz partnerska komunikacja wydają się mieć szczególne znaczenie dla procesu leczenia i trwania w abstynencji a tym samym dla jakości życia chorego. W badanej grupie - niestety - są również osoby $(18,57 \%)$, których ocena ma wymiar zdecydowanie negatywny $-\mathrm{w}$ funkcjonowaniu rodzinnym dostrzegają one dystans i chłód emocjonalny.

W rodzinie alkoholowej relacje między małżonkami często ulegają zniszczeniu. W opinii M. Wojtal, A. Popławskiej ${ }^{12}$, stają się one jednostronne, brakuje w nich współpracy, zanikają też elementarne wartości związku opartego na miłości - bliskość, intymność, szacunek, partnerstwo, przyjaźń. Podobnych

12 M. Wojtal, A. Popławska, Agresja wobec dzieci w rodzinach z problemem alkoholowym. Przeciwdziałanie przemocy $w$ rodzinie, w: Pielegnacyjne i kliniczne aspekty opieki nad chorymi. Wybrane zagadnienia. T. 2, red. A. Steciwko, M. Wojtal, D. Żurawicka, Continuo, Wrocław 2009, s. 77. 


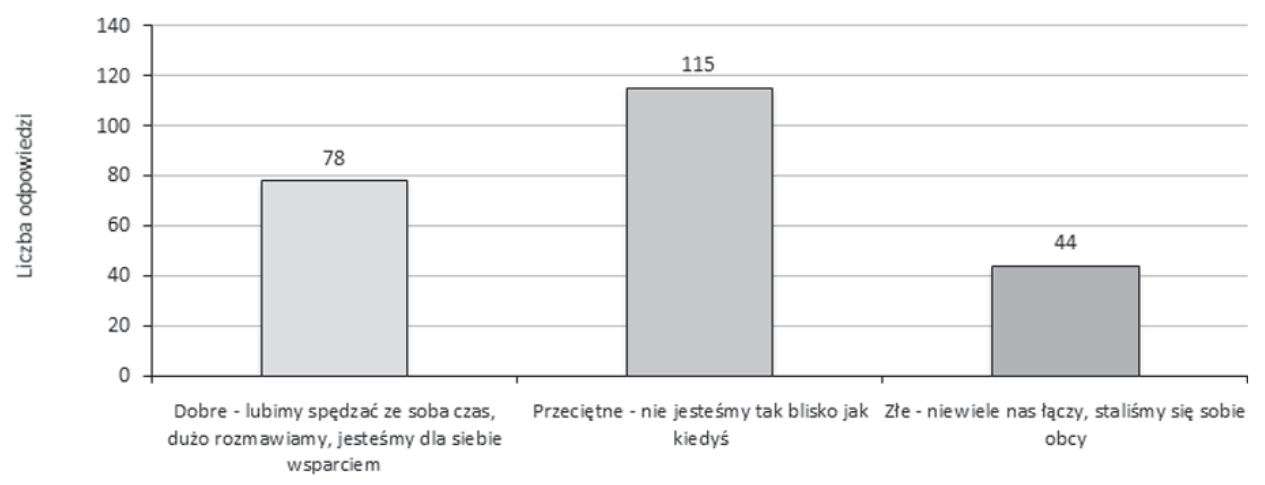

Rys. 1. Ocena obecnego życia rodzinnego

Źródło: badania własne

trudności doświadczają członkowie rodzin z problemem erotomanii. Częste konflikty, egoistyczne zachowania a niekiedy także przemoc psychiczna i/lub fizyczna powodują dysfunkcjonalność systemu rodzinnego oraz dominację w nim uczuć negatywnych. Pojawiające się kłamstwa i wymówki oraz dający się odczuć dystans i oziębłość skutecznie osłabiają relacje zaufania i bliskości między małżonkami. Rozluźnienie więzi między partnerami prowadzi niejednokrotnie do rozpadu rodziny. Prowadzone dotychczas badania wskazują, że problemów małżeńskich doświadcza ponad $70 \%$ seksoholików. Jednocześnie w wyniku choroby $40 \%$ utraciło współmałżonka lub stałego partnera, a około 13\% uzależnionych zostało pozbawione praw rodzicielskich ${ }^{13}$. Do zaburzenia relacji rodzinnych - na co wskazuje A. Derwich-Nowak ${ }^{14}$ - prowadzi również patologiczne uprawianie hazardu. Nie jest prawdą, że problem ten, to wyłącznie kłopot dotykający chorego, przeciwnie nałogowe granie i jego skutki są tak samo niszczące dla całego systemu rodzinnego, jak narkotyzowanie się czy picie alkoholu przez jednego z członków. Początkowo występujące drobne nieporozumienia (np. na tle finansowym), z czasem przeobrażają się w poważne konflikty. W rodzinie zaczynają dominować wzajemne pretensje i oskarżenia oraz nieustanne podejrzenia i wymówki, a w efekcie częste kłótnie. Brak świadomości, że hazardzista jest chory, powoduje że jego działania interpretowane są przez członków rodziny w kategoriach wyrachowanych ataków

13 I. Niewiadomska, M. Brzezińska, B. Lelonek, Seks, Gaudium, Lublin 2005, s. 140.

14 A. Derwich-Nowak, Patologiczny hazard. Poradnik dla osób grających niebezpiecznie, zagrożonych schorzeniem, ich rodzin oraz terapeutów, Difin, Warszawa 2010, s. 122. 
przeciw najbliższym. Jak pokazują badania, ponad połowa hazardzistów (59\%) jest skłócona ze swoją rodziną ${ }^{15}$.

Mając na uwadze powyższe rozważania, postanowiono skoncentrować się na relacjach rodzinnych badanej populacji. W związku z tym respondentów zapytano, czy relacje te uległy jakiejś zmianie na skutek uzależnienia i - jeśli tak - na czym ta zmiana polegała i jakich osób dotyczyła (zob. rys. 2 i tabelę 2., 3.).

Jak się okazało w przypadku większości osób nałóg był przyczyną zmian w relacjach rodzinnych - taką prawidłowość, w większym lub mniejszym stopniu, dostrzega aż 198 ankietowanych (83,54\%). W grupie tej, respondenci przeważnie z całym przekonaniem deklarowali ową zmianę (56,12\%), choć byli również tacy, dla których zmiana ta była raczej nieznaczna (27,42\%). Pozostała część badanych, stanowiąca zdecydowaną mniejszość (16,46\%), uznała, że w czasie choroby ich relacje z pozostałymi członkami rodziny nie uległy jakimkolwiek przeobrażeniom (zob. rys. 2.).

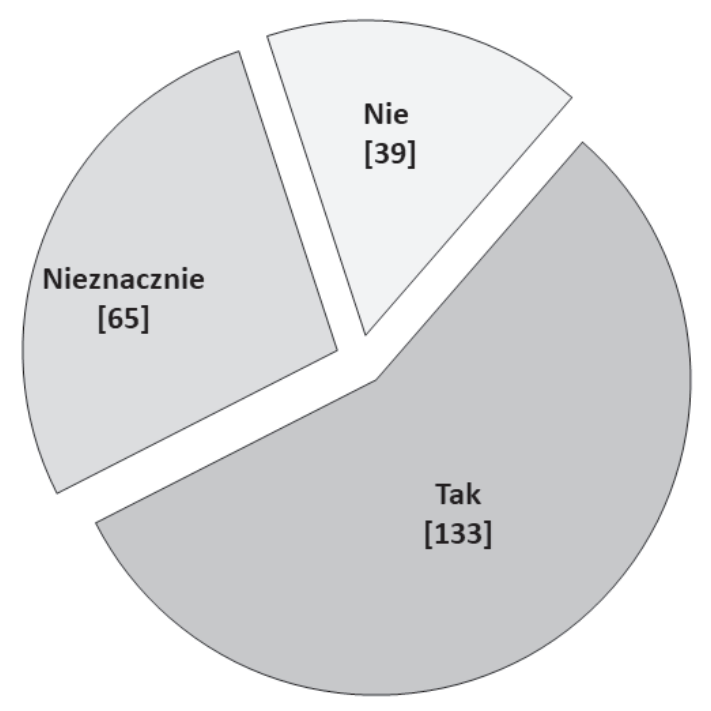

Rys. 2. Zmiana relacji rodzinnych na skutek uzależnienia

Źródło: badania własne

Jeśli chodzi o charakter zmian w relacjach rodzinnych, badani najczęściej wskazywali na pojawiający się brak zaufania ze strony bliskich $(24,24 \%)$, generujący nierzadko liczne podejrzenia i wzmożoną kontrolę chorego. Niestety, uzależnienie w wielu przypadkach było przyczyną rozwodu czy też rozstania z partnerem/ partnerką - takiej odpowiedzi udzieliło 16,16\% ankietowanych. Respondentom stosunkowo często $(13,13 \%)$ brakuje dotychczasowej bliskości, we wzajemnych

15 I. Niewiadomska, M. Brzezińska, B. Lelonek, Hazard...dz. cyt., s. 157. 
relacjach pojawia się większy dystans i chłód emocjonalny. Spora grupa osób $(10,61 \%)$ skarży się również na częste konflikty i kłótnie. Niektóre osoby $(3,54 \%)$ wskazywały nawet, że we wzajemnych kontaktach zaczęła dominować nerwowość i agresja. Inni badani (8,59\%) dostrzegają natomiast oddalenie się od rodziny i zaniedbywanie najbliższych. Ich zdaniem spędzają oni znaczenie mniej czasu z pozostałymi członkami rodziny. Ponadto kilka osób przyznało, że coraz częściej spotyka się z krytyką i wypominaniem błędów przez bliskich. Co ciekawe, wśród badanych są również osoby w przypadku których zmiany w relacjach rodzinnych miały zdecydowanie pozytywny charakter. Część z nich wskazała, że wraz z chorobą w zachowaniach pozostałych członków rodziny dało się wyczuć większe zainteresowanie i troskę o uzależnionego i jego zdrowie, pozostali natomiast deklarowali lepszy kontakt emocjonalny i fizyczny - czego przejawem jest wspólne spędzanie czasu, rozmowy o uczuciach i wzajemnych oczekiwaniach (zob. tab. 2.).

Tabela 2. Zmiany w relacjach rodzinnych $\mathrm{w}$ opinii respondentów ${ }^{16}$

\begin{tabular}{|l|c|c|}
\hline \multicolumn{1}{|c|}{ Wyszczególnienie } & Liczba & Procenty \\
\hline Brak zaufania ze strony bliskich & 48 & 24,24 \\
\hline Rozwód, rozstanie z partnerem/ partnerką & 32 & 16,16 \\
\hline Brak bliskości, większy dystans, chłód emocjonalny & 26 & 13,13 \\
\hline Nerwowość, agresja & 7 & 3,54 \\
\hline Ciągłe kłótnie & 21 & 10,61 \\
\hline Trudności w kontaktach z bliskimi z powodu poczucia winy & 4 & 2,02 \\
\hline Oddalenie się od rodziny, zaniedbywanie bliskich & 17 & 8,59 \\
\hline Krytyka, wypominanie popełnionych błędów & 7 & 3,54 \\
\hline Poczucie wstydu podczas rozmów o chorobie i jej konsekwencjach & 3 & 1,52 \\
\hline Utrata rodziny, konflikt, całkowity brak kontaktu & 9 & 4,55 \\
\hline Zbliżenie się do siebie, lepszy kontakt & 11 & 5,05 \\
\hline
\end{tabular}

16 Można było dokonać więcej nic jednego wyboru; na pytanie odpowiadali jedynie respondenci, którzy wcześniej zadeklarowali zmianę relacji rodzinnych. 


\begin{tabular}{|l|c|c|}
\hline \multicolumn{1}{|c|}{ Wyszczególnienie } & Liczba & Procenty \\
\hline Wzmożone zainteresowanie i troska o mnie i moje zdrowie & 13 & 6,57 \\
\hline Brak odpowiedzi & 36 & 18,18 \\
\hline
\end{tabular}

Źródło: badania własne

Wskazane przez respondentów zmiany w relacjach rodzinnych dotyczyły przeważnie najbliższych członków systemu rodzinnego (zob. tab. 3). Badani najczęściej (42,93\%) wskazywali, że zmiana ta dotyczyła współmałżonka czy też partnera/ partnerki. Nieco rzadziej w odpowiedziach pojawiały się dzieci $(28,79 \%)$ i rodzice (19,70\%). Najrzadziej-zdaniem respondentów - zmianie ulegały relacje z rodzeństwem. Wśród ankietowanych, jedynie nieliczne osoby uznały, że wraz z chorobą przeobrażeniu uległy relacje z dalszymi krewnymi (ciocia, teściowa, szwagier).

Tabela 3. Osoby, których dotyczyla zmiana relacji rodzinnych ${ }^{17}$

\begin{tabular}{|l|c|c|}
\hline Wyszczególnienie & Liczba & Procent \\
\hline Męża/żony, partnera/partnerki & 85 & 42,93 \\
\hline Dzieci & 57 & 28,79 \\
\hline Rodziców & 39 & 19,70 \\
\hline Rodzeństwa & 20 & 10,10 \\
\hline Inni & 5 & 2,53 \\
\hline Brak odpowiedzi & 36 & 18,18 \\
\hline
\end{tabular}

Źródło: badania własne

Zastanawiano się czy badani posiadają łatwość rozmawiania z bliskimi o swoim nałogu oraz związanych z nim problemach, a także, czy codzienne kontakty z rodziną sprawiają respondentom jakąś trudność $\mathrm{i}$ - jeśli tak - na czym ona polega. Wyniki badań przedstawiają rysunki 3. i 4.

17 Można było dokonać więcej niż jednego wyboru; na pytanie odpowiadali jedynie respondenci którzy wcześniej zadeklarowali zmianę relacji rodzinnych. 


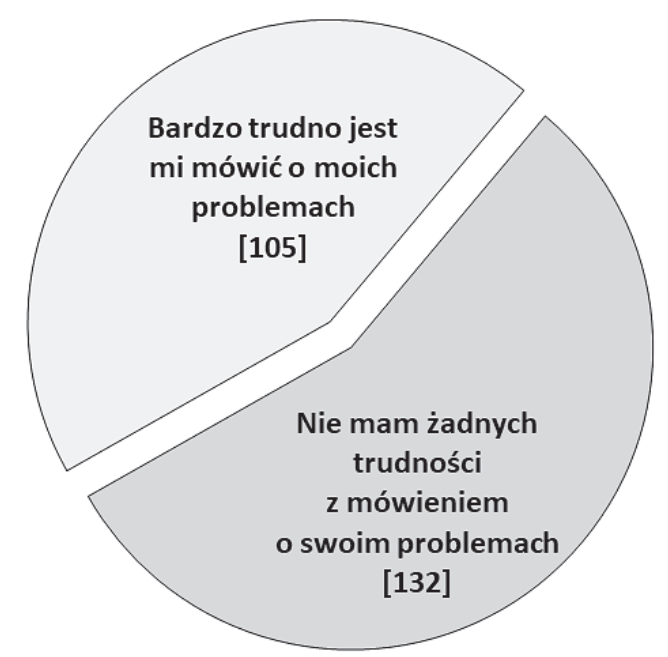

Rys. 3. Latwość rozmawiania o swoich problemach z bliskimi

Źródło: badania własne

Ustalono, że większość badanych z łatwością rozmawia o uzależnieniu i przeżywanych rozterkach - takiej odpowiedzi udzieliło 132 ankietowanych (55,70\%). Trzeba jednak przyznać, że różnice pomiędzy dwoma rodzajami odpowiedzi były nieznaczne. Dla pozostałych 105 respondentów (44,30\%) mówienie o chorobie i łączących się z nią problemach nie jest czymś łatwym - sprawia im to bowiem niemałą trudność.

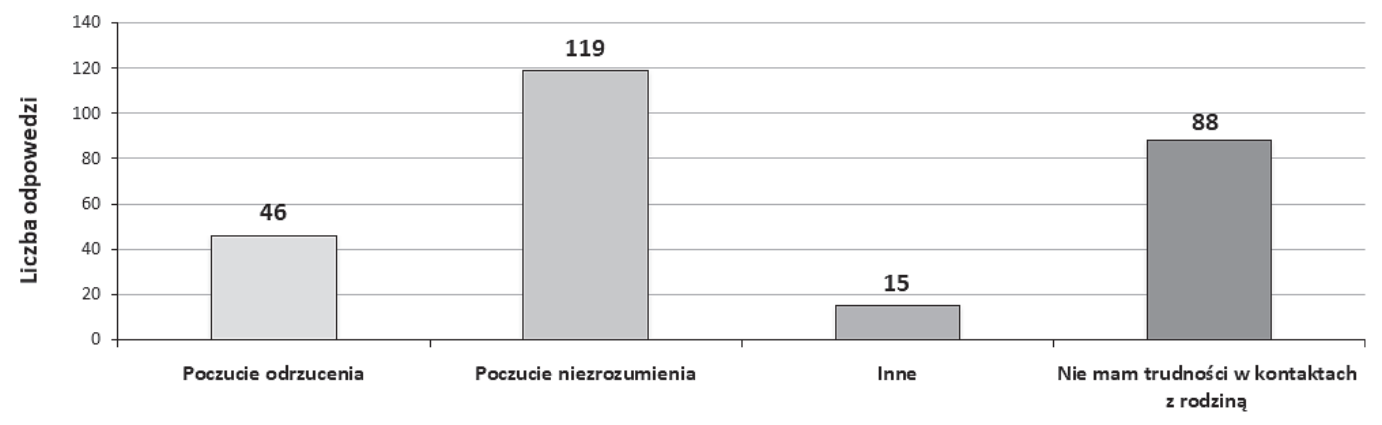

Rys. 4. Trudności w codziennych kontaktach z rodziną.

Liczba wskazań nie sumuje się do 237, ponieważ można było dokonać więcej niż jednego wyboru

Źródło: badania własne

Jednocześnie, aż 180 badanych (75,95\%) przyznaje, że na co dzień, w kontaktach $\mathrm{z}$ pozostałymi członkami rodziny odczuwa pewną barierę. W grupie tej respondenci najczęściej deklarowali, że jest to obawa przed brakiem zrozumienia, choć były również osoby $(19,41 \%)$ dla których poczucie odrzucenia, swoistego rodzaju 
brak akceptacji stanowiły największą przeszkodę w kontaktach z bliskimi. Część osób $(6,33 \%)$ wskazywała również na „inne” trudności, rozumiejąc pod pojęciem „,inne” przede wszystkim poczucie winy i wstydu, brak zaufania, bagatelizowanie problemów czy nieliczenie się ze zdaniem chorego. Pozostali badani - stanowiący mniejszą grupę (37,13\%) - nie doświadczają jakichkolwiek trudności w kontaktach $\mathrm{z}$ rodziną. Wyniki te znajdują potwierdzenie $\mathrm{w}$ innych badaniach. Również T.B. Kulik i wsp. ${ }^{18}$ zaobserwowali istnienie barier w porozumiewaniu się między alkoholikiem jego rodziną.

Według A. Słowik-Gabryelskiej ${ }^{19}$ egoistyczne ukierunkowanie wszystkich uczuć, pragnień oraz działań na zdobycie i przyjęcie kolejnej dawki, kolejnej porcji alkoholu czy innego środka odurzającego prowadzi najczęściej do zaburzenia relacji z dziećmi. Degradacja intelektualna i brak jakiejkolwiek inwencji staje się przyczyną licznych trudności, czy wręcz niezdolności nawiązywania kontaktów z innymi ludźmi, a zwłaszcza z dziećmi. Jednocześnie osoba uzależniona, tak bardzo skoncentrowana na różnego rodzaju używkach czy zachowaniach coraz częściej nie ma ochoty ani czasu na zajmowanie się swoim potomstwem - na bycie po prostu razem.

W związku z tym postanowiono sprawdzić jak kształtują się relacje badanych $\mathrm{z}$ ich dziećmi. Próbę taką podjęto w niniejszym badaniu, gdy zapytano respondentów jak oceniają aktualny kontakt z własnymi dziećmi (zob. rys. 5.).

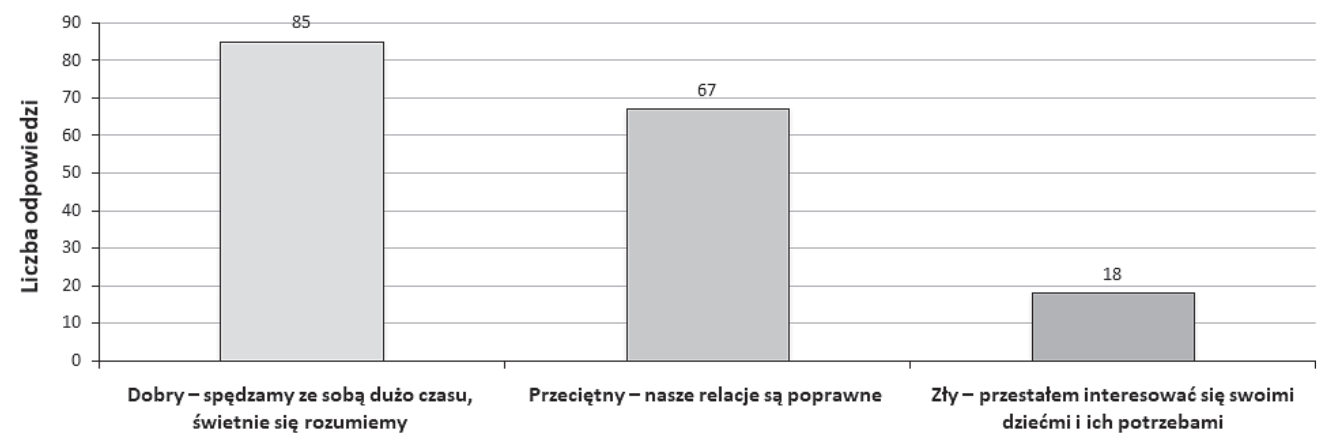

Rys. 5. Ocena kontaktu z własnymi dziećmi

Liczba wskazań nie sumuje się do 237, ponieważ nie wszyscy respondenci posiadają dzieci

Źródło: badania własne

18 T.B. Kulik, E. Rudnicka-Drożak, Rodzina-opinie, oczekiwania alkoholików grupy AA (Anonimowych Alkoholików), „Sztuka leczenia” 2000, nr 1 (6), s. 43-46.

19 A. Słowik-Gabryelska, Patologie społeczne. Alkoholizm, narkomania, nikotynizm, Wydawnictwo Naukowe Uniwersytetu Szczecińskiego, Szczecin 2006, s. 34. 
Wyniki badań wykazały, że połowa ankietowanych (50,00\%) ocenia relacje z dziećmi jako „dobre”. Osoby te deklarowały, że spędzają z nimi dużo czasu i doskonale się rozumieją. Niestety niewiele mniej badanych $(39,41 \%)$ oceniło kontakt z dziećmi na poziomie przeciętnym, tym samym przyznając, że wzajemne relacje są jedynie poprawne. W badanej populacji - co niepokojące - są również rodzice, którzy jak sami twierdzą, przestali interesować się swoimi dziećmi i ich potrzebami $(10,59 \%)$.

Sytuacja psychospołeczna rodziny z problemem uzależnienia jest szczególna, a specyfika ta uwydatnia się jeszcze wyraźniej w przypadku przemocy, która nierzadko staje się integralną częścią życia w rodzinie z osobą uzależnioną ${ }^{20}$. Zgodnie z prowadzonymi w Polsce rejestrami policyjnymi, w roku 2011 odnotowano w skali krajowej 72 tysiące sprawców przemocy domowej (95\% mężczyzn) i 113,5 tysiąca ich ofiar (62,3\% kobiet). Jednocześnie dane statystyczne wskazują, że 63\% sprawców przemocy w chwili popełnienia czynu znajdowało się pod wpływem alkoholu ${ }^{21}$. Powszechne postrzeganie przemocy - zgodnie z ujęciem I. Pospiszyl ${ }^{22}$ - opiera się na założeniu, że są to „wszelkie nieprzypadkowe akty godzące w osobistą wolność jednostki lub przyczyniające się do fizycznej, a także psychicznej szkody osoby, wykraczające poza społeczne zasady wzajemnych relacji”. Zdaniem M. Ciesielskiej ${ }^{23}$, przemoc w rodzinie charakteryzuje się tym, że:

- jest intencjonalna - podejmowane działania mają charakter nieprzypadkowy i zamierzony, ich celem jest podporządkowanie sobie ofiary,

- $\quad$ siły są nierównomierne - w sytuacji przemocy jedna z osób ma przewagę nad drugą, co oznacza, że ofiara jest słabsza a sprawca silniejszy,

- narusza prawa i dobra osobiste - sprawca przemocy wykorzystując przewagę siły odbiera swoim ofiarom ich podstawowe prawa i dobra (m.in. prawo do wolności osobistej, nietykalności fizycznej, godności i szacunku),

- powoduje cierpienie i ból - zachowanie sprawcy naraża ofiarę na poważne szkody, fizyczne i psychiczne, które osłabiają jej zdolność do samoobrony. Problem przemocy w sytuacji uzależnienia jednego z członków rodziny jest dużo bardziej złożony niż powszechnie łączone w mentalności społecznej z libacjami

20 D. Chlebio-Abed, Pierwotna profilaktyka ... dz. cyt., s. 46.

21 P. Serafin i in., Przemoc między partnerami i zachowania ryzykowne u osób uzależnionych od alkoholu i innych substancji psychoaktywnych. „Alkoholizm i Narkomania” 2012, nr 3 (25), s. 289-305.

22 I. Pospiszyl, Przemoc w rodzinie, WSiP, Warszawa 1994, s. 14.

23 M. Ciesielska, Rodzaje, formy i cykl przemocy $w$ rodzinie, „Zeszyty Naukowe Państwowej Wyższej Szkoły Zawodowej im. Witelona w Legnicy” 2014, nr 12 (3), s. 7-16. 
alkoholowymi kłótnie czy bójki. Rzadko zdarza się bowiem, żeby sprawca stosował wobec swojej ofiary tylko jedną formę przemocy - przeważnie wykorzystuje różne jej rodzaje, łącząc je na przemian tak, by osiągnąć całkowitą kontrolę nad drugą osobą. Niewątpliwie tą najbardziej widoczną jest przemoc fizyczna, pozostawiająca liczne ślady w postaci siniaków, zadrapań, złamań. Najczęściej występujące jej przejawy, to potrząsanie, szarpanie za włosy, duszenie, bicie dłonią lub przedmiotami, kopanie oraz te bardziej drastyczne sposoby np. polewanie wrzątkiem czy przypalanie. Specyficzną formą przemocy występującej w rodzinie z problemem uzależnienia jest przemoc o charakterze psychicznym. W tym przypadku sprawca sięga po takie środki jak grożenie, obrażanie, ośmieszanie, zawstydzanie, poniżanie (często w obecności innych osób) a także izolowanie od bliskich i szerszego otoczenia. Choć efekty jego działań są mniej widoczne na zewnątrz niż w przypadku agresji fizycznej, nie mniej jednak skutki tego rodzaju przemocy są wysoce szkodliwe i mogą prowadzić do nieodwracalnych zmian w funkcjonowaniu ofiary. Kolejnym ważnym aspektem poruszanego problemu jest współwystępująca przemoc seksualna. Definiowana jest ona jako wymuszanie różnego rodzaju niechcianych zachowań i kontaktów. Przeważnie obejmuje gwałty oraz zmuszanie do nieakceptowanych praktyk seksualnych i oglądania materiałów o treści pornograficznej. Stanowi najbardziej wstydliwy dla ofiary rodzaj przemocy, do której trudno się przyznać i równie trudno rozmawiać. Zdarza się także, że występująca w rodzinie przemoc przyjmuje formę ekonomiczną. Chodzi tutaj w szczególności o odmawianie lub ograniczanie dostępu do wspólnych finansów, odbieranie zarobionych pieniędzy, okradanie a także celowe niszczenie czyjejś własności ${ }^{24}$.

Analizę problemu przemocy w badanej populacji rozpoczęto od ustalenia, czy w rodzinach respondentów pojawiają się kłótnie i awantury domowe $\mathrm{i}$ - jeśli tak z jaką częstotliwością (zob. rys. 6.).

Uzyskane wyniki wykazały, że w rodzinach badanych osób - z większą lub mniejszą częstotliwością - występują kłótnie i awantury domowe. Takiej deklaracji dokonało aż 87,76\% ankietowanych. I choć w grupie tej, respondenci najczęściej $(33,76 \%)$ podawali, że pojawiają się one jedynie raz w miesiącu lub rzadziej, to niestety pozostała cześć osób wskazała na znacznie większą częstotliwość.

24 K. Michalska, D. Jaszczak-Kuźmińska, Przemoc $w$ rodzinie, w: Przemoc $w$ rodzinie wobec osób starszych niepetnosprawnych. Poradnik dla pracowników pierwszego kontaktu, red. D. Jaszczak-Kuźmińska, K. Michalska, Wydawnictwo Edukacyjne PARPAMEDIA, Warszawa 2010, s. 10-11. 


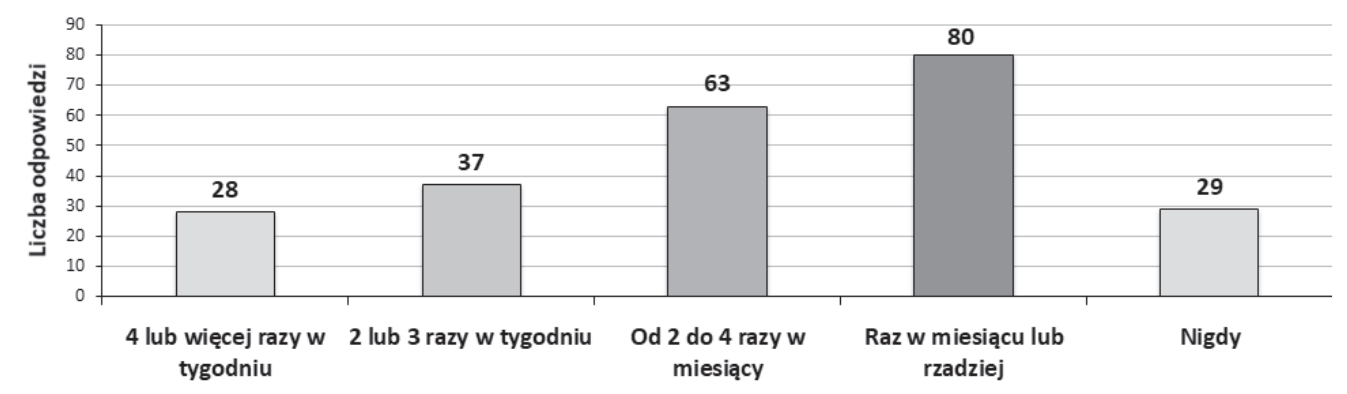

Rys. 6. Częstotliwość z jaką występują w rodzinie kłótnie i awantury domowe

Źródło: badania własne

Tymczasem - jak słusznie zauważa M. Przybysz-Zaremba ${ }^{25}$ - przebywanie w takiej atmosferze w sposób pejoratywny wpływa na wszystkich członków, jednak najboleśniej dotyka tych najmłodszych, ponieważ doświadczają oni zakłóconego procesu socjalizacyjno-wychowawczego. W badanej populacji, tylko nieliczne osoby $(12,24 \%)$ stwierdziły, że w ich rodzinach nigdy nie dochodzi do awantur.

Dodatkowo respondentów zapytano, czy zdarza im się stosować przemoc wobec członków rodziny. Wprawdzie większość z nich $(55,27 \%)$ odpowiedziała przecząco, niemniej jednak spora część osób (44,73\%) - niestety - wskazała na występowanie z jej strony aktów przemocy (zob. rys. 7.). A zatem wyraźnie widać, że potwierdzają się tezy zawarte w literaturze przedmiotu (przedstawione wcześniej), że przemoc jest obecna w rodzinach z problemem uzależnienia.

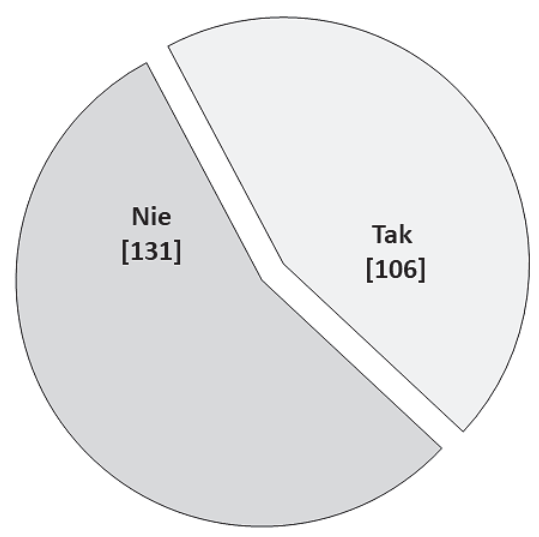

Rys. 7. Stosowanie przemocy

Źródło: badania własne

25 M. Przybysz-Zaremba, Dymorficzny wymiar uwarunkowań agresji i przemocy domowej-przegląd wybranych aspektów i eksploracji. „Studia nad Rodziną” 2015, r. XIX, nr 2(37), s. 243-259. 
Biorąc pod uwagę liczbę respondentów, którzy przyznali się do stosowania przemocy, postanowiono sprawdzić jakie formy przemocy dominują w ich zachowaniu (zob. tab. 4.).

Tabela 4. Stosowane przez badanych formy przemocy ${ }^{26}$

\begin{tabular}{|l|c|c|}
\hline \multicolumn{1}{|c|}{ Wyszczególnienie } & Liczba & Procent \\
\hline $\begin{array}{l}\text { Przemoc fizyczna } \\
\text { (np. popychanie, policzkowanie, kopanie, duszenie, bicie) }\end{array}$ & 55 & 51,89 \\
\hline $\begin{array}{l}\text { Przemoc psychiczna } \\
\text { (np. obrażanie, straszenie, poniżanie, grożenie, szantażowanie) }\end{array}$ & 86 & 81,13 \\
\hline $\begin{array}{l}\text { Przemoc seksualna } \\
\text { (np. gwałt, wymuszanie różnego rodzaju niechcianych zachowań) }\end{array}$ & 7 & 6,60 \\
\hline $\begin{array}{l}\text { Przemoc ekonomiczna } \\
\text { (np. niszczenie rzeczy, kradzież, sprzedawanie osobistych rzeczy) }\end{array}$ & 43 & 40,57 \\
\hline
\end{tabular}

Źródło: badania własne

W badanej populacji stwierdzono występowanie wszystkich rodzajów przemocy: fizycznej, psychicznej, seksualnej, ekonomicznej. Wielu respondentów nie poprzestaje tylko na jednej formie - w ich działaniach widoczne są także inne rodzaje przemocy. Najczęściej badani stosują przemoc psychiczną wobec bliskich - takiej odpowiedzi udzieliło 81,13\% ankietowanych. Na drugim miejscu znalazła się przemoc fizyczna $(51,89 \%)$ a zaraz po niej, przemoc ekonomiczna $(40,57 \%)$. Najrzadziej natomiast $(6,60 \%)$ wskazywano na przemoc o charakterze seksualnym. Jak łatwo się domyśleć, jednoczesne doświadczanie agresji i przemocy wraz z nałogowymi zachowaniami bliskiej osoby, generuje niebywałe skutki dla wszystkich członków rodziny, a zwłaszcza dla przebywających w niej dzieci.

\section{Podsumowanie}

Uzależnienie nie dotyka wyłącznie chorego. Rozszerza się ono bowiem na wszystkich bliskich żyjących we wspólnocie z osobą uzależnioną, zakłócając tym samym dotychczasowe relacje oraz implikując liczne problemy na wielu płaszczyznach życia rodzinnego. Człowiek zatracając się w swoim nałogu powoduje coraz większą dysfunkcjonalność całego systemu rodzinnego, w którym

${ }^{26}$ Można było dokonać więcej niż jednego wyboru; na pytanie odpowiadali jedynie respondenci którzy wcześniej zadeklarowali stosowanie przemocy. 
stopniowo zanika bliskość i wzajemność, a zaczyna dominować nieszczerość i zakłamanie ${ }^{27}$. Analiza zebranego materiału wydaje się potwierdzać refleksje i przekonania zawarte w literaturze przedmiotu. Aż 83,54\% badanych przyznało, że nałóg - w większym lub mniejszym stopniu - przyczynił się do zmian w ich relacjach rodzinnych. Respondenci najczęściej skarżą się na występujący we wzajemnych kontaktach brak zaufania, większy dystans i chłód emocjonalny. Podobne wyniki otrzymali A. Ryszkowski i wsp. ${ }^{28}$, którzy również dostrzegli niekorzystne oddziaływanie uzależnienia na życie rodzinne. Ponadto badania własne potwierdziły istnienie związku pomiędzy przyjmowaniem substancji psychoaktywnych a uaktywnianiem się agresji i przemocy. W badanej populacji stwierdzono występowanie wszystkich rodzajów przemocy: fizycznej, psychicznej, seksualnej, ekonomicznej. Do stosowania przemocy wobec najbliższych przyznaje się niemal połowa badanych. Istnieje więc ogromna potrzeba podejmowania działań wspierających nie tylko samych chorych, ale i cały system rodziny. Sprecyzowanie tego, jakie to powinny być działania wymaga odrębnego i szczegółowego omówienia. Kontynuacja podjętych analiz i (zarówno tych teoretycznych, jak i badawczych) wydaje się zatem niezwykle cenna.

\section{Bibliografia}

Chlebio-Abed D., Pierwotna profilaktyka uzależnienia od alkoholu. Przegląd wybranych strategii i programów, Wydawnictwo Naukowe „Śląsk”, Katowice 2010.

Ciesielska M., Rodzaje, formy i cykl przemocy w rodzinie, „Zeszyty Naukowe Państwowej Wyższej Szkoły Zawodowej im. Witelona w Legnicy” 2014, nr $12(3)$.

Derwich-Nowak A., Patologiczny hazard. Poradnik dla osób grajacych niebezpiecznie, zagrożonych schorzeniem, ich rodzin oraz terapeutów, Difin, Warszawa 2010.

Garniewicz A., Problemy alkoholowe w rodzinie a jakość życia, w: Jakość życia młodzieży ze środowisk zagrożonych patologia społeczna, red. Z. Palak M.

27 A. Garniewicz, Problemy alkoholowe w rodzinie a jakość życia, w: Jakość życia młodzieży ze środowisk zagrożonych patologia społeczna, red. Z. Palak i in., Wydawnictwo Naukowe PWSZ, Tarnobrzeg 2011, s. 31.

28 A. Ryszkowski i in., Uczestnicy klubu Anonimowych Alkoholików o swoim nałogu i jego skutkach $w$ wieloośrodkowych badaniach ankietowych, „Journal of Clinical Healthcare" 2015, nr 1, s. 25-30. 
Piątek, A. Róg, B. Zięba-Kołodziej, Wydawnictwo Naukowe PWSZ, Tarnobrzeg 2011.

Jedynak M., Alkoholizm jako zjawisko patologiczne i społecznie destruktywne, w: Uzależnienia oraz zwiazane z nimi zagrożenia społeczne, red. D. Pstrąg, Wydawnictwo Uniwersytetu Rzeszowskiego, Rzeszów 2014.

Kawczyńska-Butrym Z., Wyzwania rodziny: zdrowie, choroba, niepetnosprawność, starość, Wydawnictwo Makmed, Lublin 2008.

Kozłowska D., Łodzińska J., Świadomość skutków zdrowotnych nadużywania alkoholu przez dorostych na podstawie badań przeprowadzonych w śród mtodzieży gimnazjalnej i osób dorostych w Łomży. „Zeszyty Naukowe. Wyższa Szkoła Agrobiznesu w Łomży” 2013, nr 49.

Kulik T.B., Rudnicka-Drożak E., Rodzina-opinie, oczekiwania alkoholików grupy AA (Anonimowych Alkoholików), ,Sztuka leczenia” 2000, nr 1 (6).

Maszke A.W., Metody i techniki badań pedagogicznych, Wydawnictwo Uniwersytetu Rzeszowskiego, Rzeszów 2008.

Mellibruda J., Tajemnice ETOH, czyli alkohol i nasze życie, PARPA, Warszawa 1993.

Michalska K., Jaszczak-Kuźmińska D., Przemoc w rodzinie, w: Przemoc w rodzinie wobec osób starszych niepetnosprawnych. Poradnik dla pracowników pierwszego kontaktu, red. D. Jaszczak-Kuźmińska, K. Michalska, Wydawnictwo Edukacyjne PARPAMEDIA, Warszawa 2010.

Niewiadomska I., Brzezińska M., Lelonek B., Hazard, Gaudium, Lublin 2005.

Niewiadomska I., Śpiła B., Chwaszcz J., Kołodziej B., Seks, Gaudium, Lublin 2005. Pilch T., Bauman T., Zasady badań pedagogicznych: strategie ilościowe i jakościowe, Wydawnictwo Akademickie „Żak”, Warszawa 2001.

Pospiszyl I., Przemoc w rodzinie, WSiP, Warszawa 1994.

Przybysz-Zaremba M., Dymorficzny wymiar uwarunkowań agresji i przemocy domowej - przeglą wybranych aspektów i eksploracji. „Studia nad Rodziną” 2015, r. XIX, nr 2(37).

Ryszkowski A. Wojciechowska A., Kopański Z., Brukwicka I., Lishchynskyy Y., Uracz W., Mazurek M., Uczestnicy klubu Anonimowych Alkoholików o swoim nałogu i jego skutkach w wieloośrodkowych badaniach ankietowych, „Journal of Clinical Healthcare" 2015, nr 1.

Ryszkowski A., Funkcjonowanie w społeczeństwie osób uzależnionych od alkoholu. „Journal of Clinical Healthcare” 2015, nr 1.

Serafin P., Jakubczyk A., Podgórska A., Topolewska-Wochowska A., Wojnar M., Przemoc między partnerami i zachowania ryzykowne u osób uzależnionych od alkoholu i innych substancji psychoaktywnych. „Alkoholizm i Narkomania” 2012, nr 3 (25). 
Słowik-Gabryelska A., Patologie społeczne. Alkoholizm, narkomania, nikotynizm, Wydawnictwo Naukowe Uniwersytetu Szczecińskiego, Szczecin 2006.

Syrek E., Zdrowie $i$ wychowanie a jakość życia. perspektywy $i$ humanistyczne orientacje poznawcze, Wydawnictwo Uniwersytetu Śląskiego, Katowice 2008. Szczukiewicz P., System rodzinny a pomaganie osobom uzależnionym. „Terapia: uzależnienia i współuzależnienia" 2013, nr 2.

Taranowicz I., Rodzina a problemy zdrowia $i$ choroby, w: Zdrowie i choroba. Wybrane problemy socjologii medycyny, red. J. Barański, W. Piątkowski, Wydawnictwo Oświatowe ATUT, Wrocław 2002.

Wojtal M., Popławska A., Agresja wobec dzieci w rodzinach z problemem alkoholowym. Przeciwdziałanie przemocy w rodzinie, w: Pielęgnacyjne i kliniczne aspekty opieki nad chorymi. Wybrane zagadnienia. T. 2, red. A. Steciwko, M. Wojtal, D. Żurawicka, Continuo, Wrocław 2009.

\title{
Julia Dziukiewicz: Psychosocial situation of families with the problem of addiction
}

\begin{abstract}
Summary
Addiction is not only the problem which affects the ill. That is the family, constituting the closest environment of the addicted person, that is the most vulnerable to their destructive influence. Most frequently, addiction of a family member disturbs functions and structure of the whole family system. Creation of an empirical image of the psychosocial situation of families with the problem of addiction, i.e. determination how patients of rehab facilities assess their own relationships within their families, is the main purpose of the article. Both persons addicted to psychoactive substances (such as alcohol and drugs) and persons addicted to different kinds of behaviour (mostly sex and gambling) were invited to participate in the study. A self-designed questionnaire was used to collect the data.
\end{abstract}

Key words: addiction, family relationships, crisis, illness, domestic violence. 